\title{
Graphene oxide flake activation via divinylsulfone - a procedure for efficient $\beta$-galactosidase immobilization
}

\author{
Anna Trusek \\ Wroclaw University of Science and Technology, Department of Bioprocess and Biomedical Engineering, Norwida 4/6, \\ 50-373 Wroclaw, Poland \\ *Corresponding author: e-mail: anna.trusek@pwr.edu.pl
}

\begin{abstract}
Flaky graphene oxide was activated with divinylsulfone followed by immobilization of the $\beta$-galactosidase enzyme. An active and stable preparation was obtained. $\beta$-galactosidase stability after immobilization was much higher than with the native enzyme. The half-life time of the immobilized enzyme was estimated as 165 hours, while for the native form, the estimate was only 5 hours. The developed procedure for the preparation of flaked graphene and its use in the chemical immobilization of enzymes can be used for any enzyme. A processing solution for continuous operation was proposed and verified using cow's milk, with lactose as the hydrolysed substrate, as a dosing stream. Lactose, a milk sugar, was effectively hydrolysed. Product for allergy sufferers who cannot digest lactose has been obtained in this way.
\end{abstract}

Keywords: graphene oxide; enzyme chemical immobilization; divinylsulfone; $\beta$-galactosidase; lactose-free product.

\section{INTRODUCTION}

Graphene is made up of a single layer of tightly packed carbon atoms that form a two-dimensional (2D) hexagonal plane, resembling a honeycomb structure. It is characterized as a flat structure composed of $\mathrm{sp} 2$ carbon atoms, while the carbon-carbon bond length is approximately $0.142 \mathrm{~nm}^{1}$. Graphene is a light and very thin material with a specific density of $0.77 \mathrm{mg} / \mathrm{m}^{2}$ and a thickness of $0.35 \mathrm{~nm}$. Nevertheless, the structure of graphene is quite stable due to the bonds that occur between carbon atoms ${ }^{1}$.

Despite the fact that graphene is the basic building block of various carbon forms, it was first produced in 2004, which is 440 years after the invention of graphite, by breaking off a single layer of graphene from graphite using adhesive tape and a pencil ${ }^{2}$. Over the past few years, various graphene methods have been developed, such as $^{3}$ micromechanical peeling (micromechanical exfoliation), chemical vapor deposition (chemical epitaxy with CVD deposition), epitaxial growth, and chemical synthesis from graphite.

The chemical method of graphene production involves the preliminary oxidation of graphite to graphite oxide, followed by the mechanical or thermal exfoliation of graphite oxide to graphene oxide sheets. To obtain pure graphene, a chemical reduction is carried out, during which functional groups are removed ${ }^{3}$. In Fig. 1, basic structures of graphene and graphene oxide (GO) are presented.

Graphene oxide (GO) is characterized by an unusually large surface area. It has two available sides on which there are oxygen-rich functional groups, such as hydroxyl and epoxide, which are embedded on the inner part of the material, and carboxylic and carbonyl groups arranged on its edges. These groups ensure high solubility of this material in water, and this property has promise for many applications ${ }^{4}$.

Due to their unique chemical and physical properties, (nano)materials based on graphene and GO have been used in many fields, such as quantum physics, nanoelectronics, catalysis, biomaterials and drug delivery. These

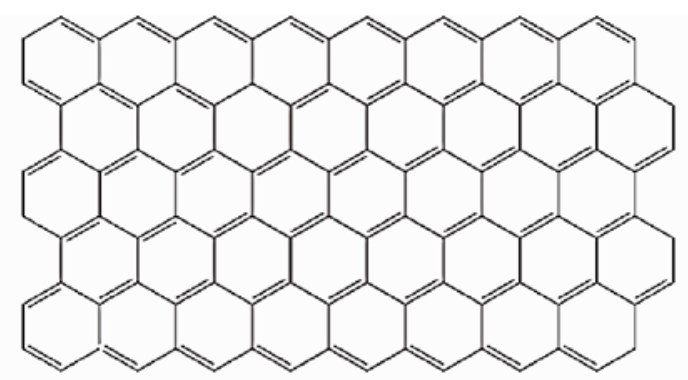

Graphene

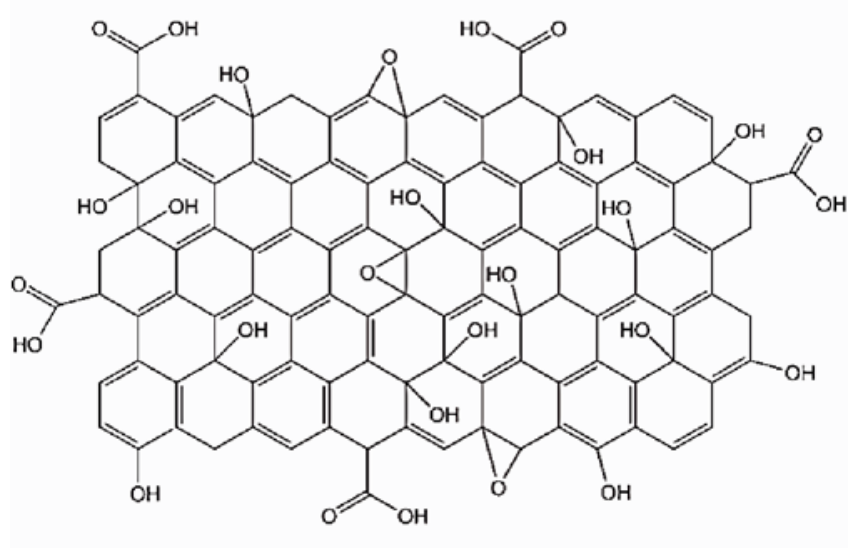

Graphene oxide (GO)

Figure 1. Structural model of graphene and graphene oxide (GO)

materials have been used to create functionalized biosystems integrated with nucleic acids, peptides, proteins (including enzymes) and cells ${ }^{2}$.

Immobilization of enzymes on the surface of graphene oxide (GO) may occur through ${ }^{5}$ physical adsorption; i.e., non-covalent binding by weak interactions between the carrier and the immobilized enzyme, or chemical adsorption, which is due to covalent binding using a cross-linking agent or also by activation of functional groups located on the GO surface.

Graphene oxide sheets have a large specific surface area and have many functional groups, which proves that this material is an ideal substrate for immobilizing enzymes. 
It has been shown that immobilization of enzymes on GO sheets can take place without the use of cross-linking reagents or additional surface modification. Binding of enzyme molecules to GO occurs mainly through electrostatic interactions ${ }^{5}$. Thanks to these interactions, among others, effective immobilization of horseradish peroxidase (HRP) and lysozymes ${ }^{6}$ and catalase $^{7}$ was carried out. $\beta$-galactosidase was bound also by chemical bonds ${ }^{8}$ when graphene sheets were functionalized by a glutaraldehyde solution. One arm of glutaraldehyde binds to the -NH2 group of cysteamine through the $-\mathrm{CHO}$ group, while the other arm remain available for interaction with enzymes via lysine residues. After this immobilization, an increase in the thermal stability of the immobilized enzyme was noted. The immobilized $\beta$-galactosidase showed excellent suitability for reuse with more than $92 \%$ enzyme activity after 10 reuses $^{8}$.

The aim of this work was activation of graphene oxide with divinylsulfone for further chemical immobilization of the selected enzyme; i.e., $\beta$-galactosidase. Divinylsulfone is one of several bifunctional agents that has been applied often in protein immobilization ${ }^{9,10}$ mainly because of its stability in water, high yields under mild operational conditions, and stability of the bond between proteins and the support. In addition, no particular byproducts are generated during activation. Divinylsulfone is able to activate mainly alcoholic $(-\mathrm{OH})$ groups of the carrier. Cysteine $-\mathrm{SH}$ groups are then the principal residues involved in protein coupling ${ }^{\mathbf{1 1}}$.

A procedure for immobilization on graphene flakes has been developed. Due to difficulties in separating graphene flakes, the immobilization process had to be modified in relation to standard procedures ${ }^{\mathbf{1 2}}$. The efficiency of enzyme binding and the activity and stability of the preparation under a processing condition were tested. A processing solution for continuous operation is proposed.

\section{MATERIALS AND METHODS}

\section{Graphene oxide activation via divinylsulfone}

Graphene oxide $\left(\mathrm{GO}\right.$ in $\left.\mathrm{H}_{2} \mathrm{O}\right)$ was obtained from the Graphene Laboratory of the Center of Advanced Studies Warsaw University of Technology (Poland). GO was washed twice with distilled water and centrifuged each time using a Universal $320 \mathrm{R}$ centrifuge (Germany) at 10,000 RPM for $30 \mathrm{~min}$ followed by removal of the supernatant. Next, $10 \%$ v/v divinylsulfone (Sigma) was added to the graphene flakes, and the activation procedure was performed according to the scheme presented in Fig. 2. Horizontal shaking with an SM 30 (E. Buhler, Germany) was used.

\section{Enzyme immobilization}

The procedure for enzyme immobilization is presented in Fig. 3. $\beta$-galactosidase from Kluyveromyces lactic solution (Sigma, G3665) was diluted 20-times with $0.4 \mathrm{M}$ carbonate buffer, $\mathrm{pH}$ 8.0, and added to dry graphene flakes. The ratio of the enzymatic solution to graphene was $10 \mathrm{~mL}$ to $20 \mathrm{mg}$.

The immobilization procedure was carried out at $3{ }^{\circ} \mathrm{C}$ for 3 hours in a shaking (120 RPM) flask. Then, centrifu-

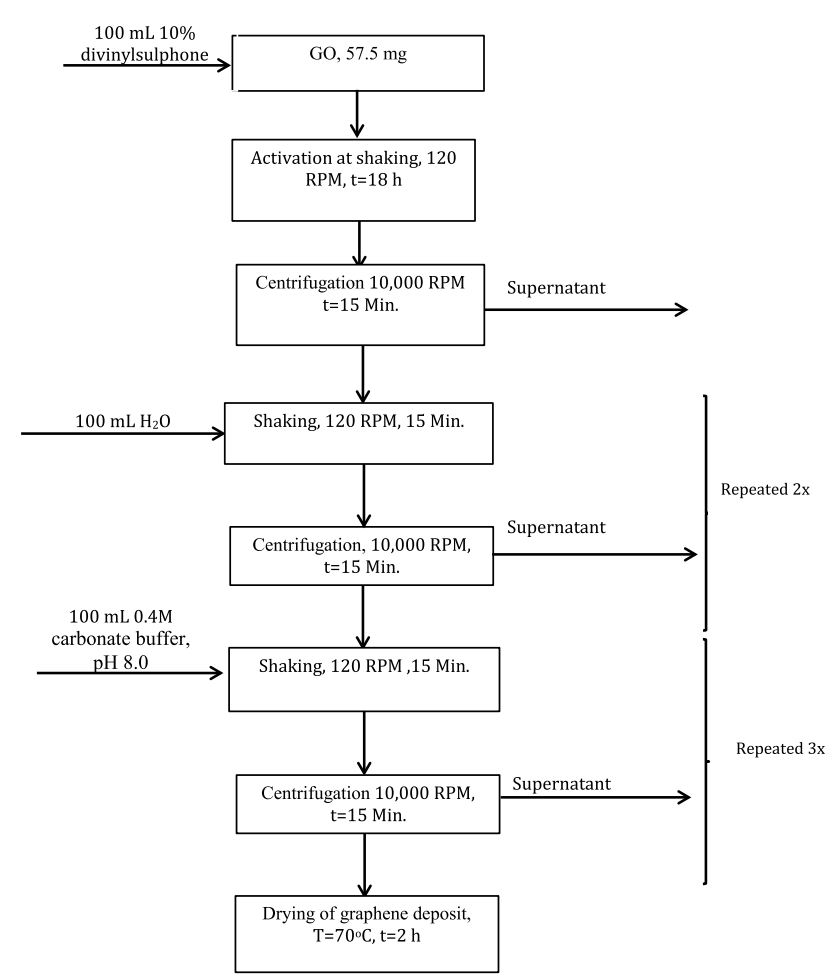

Figure 2. Activation procedure via divinylsulfone

gation at $10,000 \mathrm{RPM}$ at $3^{\circ} \mathrm{C}$ for 30 min was applied to separate the solution and the graphene flakes with the immobilized enzymes. Graphene was washed three times with $0.05 \mathrm{M}$ Tris-HCl buffer ( $\mathrm{pH}$ 7.0) and shaken each time for $15 \mathrm{~min}$. Immobilization efficiency was based on the protein mass balance. The enzyme concentration was measured at $280 \mathrm{~nm}(\mathrm{~A}(280 \mathrm{~nm})=0.982 \cdot \mathrm{C}[\mathrm{g} / \mathrm{L}])$. The measurements were made in solutions before and after immobilization and also in the first wash solution.

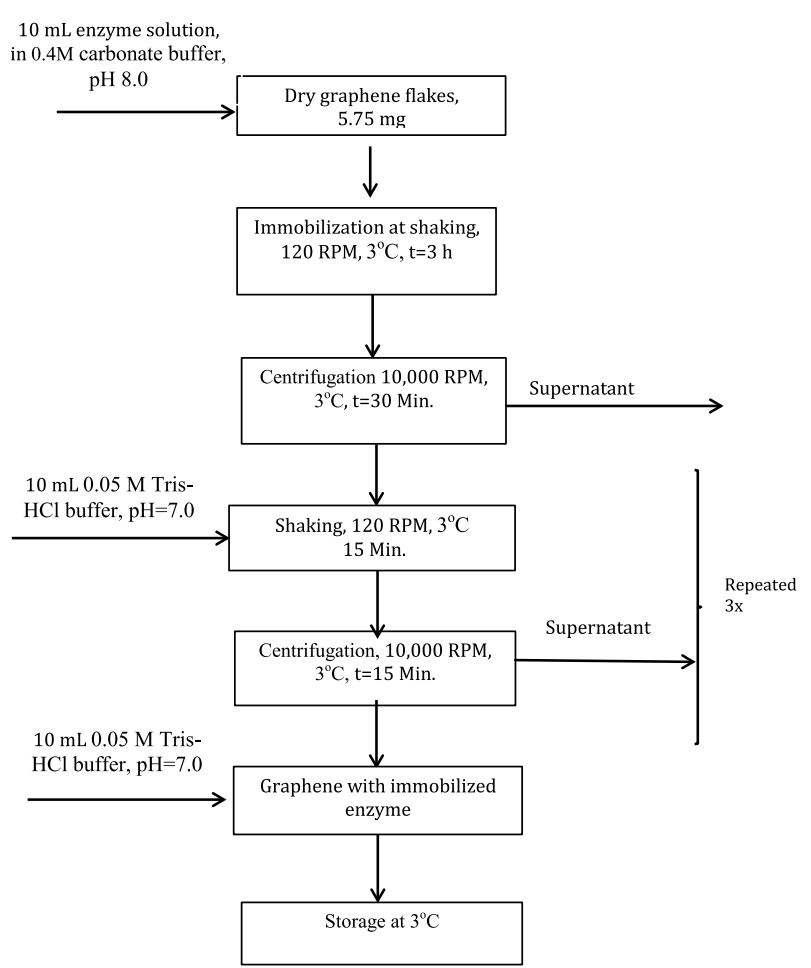

Figure 3. Immobilization procedure 


\section{Activity of immobilized enzymes}

Enzymatic activity was checked in the hydrolysis reaction of lactose. The procedure is presented in detail in Fig. 4. Graphene flakes with immobilized enzymes were centrifuged before the reaction, and the supernatant was replaced with lactose solution prepared with $0.05 \mathrm{M}$ Tris- $\mathrm{HCl}$ buffer, $\mathrm{pH}$ 6.6. The reaction was carried out in a thermostated stirring tank reactor using a Julabo Lab Circulator (model F12-MA, Germany), electromagnetic stirrer (model ES24, Wigo, Poland) and double-wall glass reactor with water circulation inside the walls. The pseudo-concentration of the enzyme in the reaction was $0.883 \pm 0.007 \mathrm{~g} / \mathrm{L}$.

The reaction with the native enzyme was performed in the range of concentrations $0.15-0.94 \mathrm{~g} / \mathrm{L}$. The reaction was carried out in a thermostated $\left(37^{\circ} \mathrm{C}\right)$ stirring tank reactor at an initial lactose concentration equal to $1 \mathrm{~g} / \mathrm{L}$.

The changes in reducing sugar concentrations were monitored across time with a DNS procedure ${ }^{\mathbf{1 3}}$. Samples of $0.6 \mathrm{~mL}$ were taken from the reactor and centrifuged for 15 minutes at 10,000 RPM, and new portions of substrate solution were added to the reactor. This procedure was considered during the reaction rate calculation.

The DNS test for each sample was prepared twice, taking $0.25 \mathrm{~mL}$ of the solution (diluted if needed) and adding $0.75 \mathrm{~mL}$ of DNS reagent, after 5 minutes of reaction at $100^{\circ} \mathrm{C}$, dissolved with $8 \mathrm{~mL}$ water. The reducing sugar concentration was calculated using the standard curve $\mathrm{A}(550 \mathrm{~nm})=0.65^{\circ} \mathrm{C}[\mathrm{g} / \mathrm{L}]$ and was verified to be in the range of $0.2-1.8 \mathrm{~g} / \mathrm{L}$; the same values were obtained for glucose and galactose as for lactose.

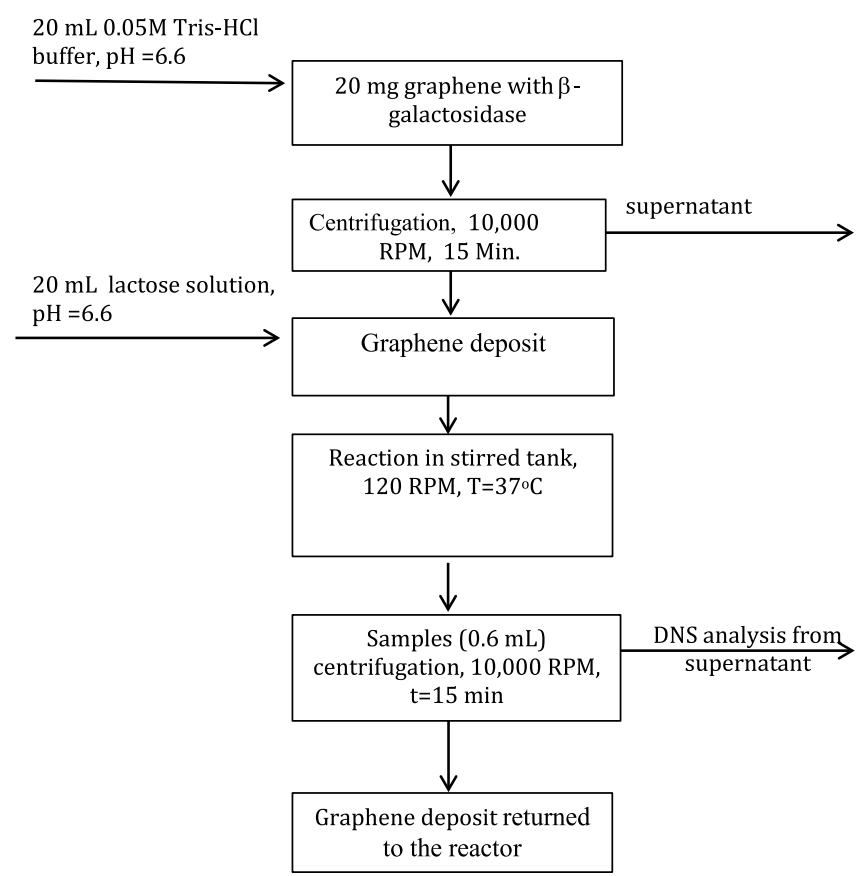

Figure 4. Reaction of lactose hydrolysis with $\beta$-galactosidase immobilized on graphene flakes

\section{Stability of immobilized enzymes}

Enzyme stability was tested under processing conditions $\left(37^{\circ} \mathrm{C}, 0.05 \mathrm{M}\right.$ Tris- $\mathrm{HCl}$ buffer, $\mathrm{pH}$ 6.6). A new substrate portion was added to obtain a final concentration in the bioreactor equal to $1 \mathrm{~g} / \mathrm{L}$, and substrate hydrolysis was monitored with a DNS test. The initial rate reaction was calculated based on the data obtained until $\alpha=0.1$. The process with the native enzyme was carried out for $12 \mathrm{~h}$ with new portion dosing every several dozen minutes, while the process with the immobilized enzyme was carried out for 10 days with new substrate portion dosing every 24 hours.

\section{Experiment with continuous processing}

A total of $20.17 \mathrm{~g}$ of graphene flakes with $8.27 \mathrm{~g}$ of immobilized $\beta$-galactosidase was suspended in $0.05 \mathrm{M}$ Tris- $\mathrm{HCl}$ buffer, $\mathrm{pH}$ 6.6, and transferred to dialysis membrane tubing (Spectrum ${ }^{\text {тм }}$ Spectra/Por ${ }^{\text {тм }} 3 \mathrm{RC}$, Fisher Scientific, Sweden). This tubing was mounted in the reactor at $5 \mathrm{~cm}$ above the agitator blades (Fig. 5).

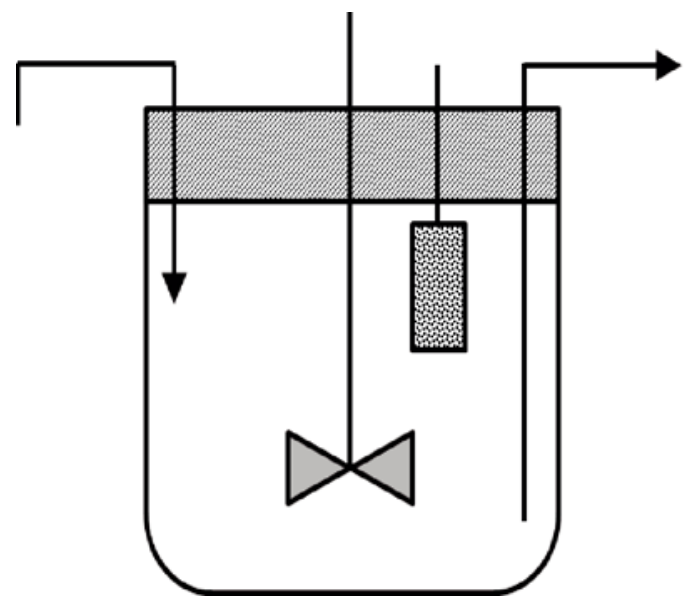

Figure 5. Scheme of the set used in the continuous process

Cow's milk (2\% fat, Laciate, Poland) was diluted 10 times with $0.05 \mathrm{M}$ Tris- $\mathrm{HCl}$ buffer, $\mathrm{pH}$ 6.6. After dilution, the lactose concentration was $4.6520 \mathrm{~g} / \mathrm{L}$. Using a Masterflex L/S Economy Variable Speed Drive Pump (Cole-Parmer, USA), this medium was dosed to the thermostated $\left(37^{\circ} \mathrm{C}\right)$ reactor tank. The volume of liquid in the reactor was 1 litre. Initially, the dosed stream was $71.4 \mathrm{~mL} / \mathrm{h}$ in order to obtain a residence time equal to $14 \mathrm{~h}$. Every 24 hours, this stream was changed to within the range $71.4-31.5 \mathrm{~mL} / \mathrm{h}$. The stream at the same value was pumped out from the reactor using a Masterflex L/S Economy Variable Speed Drive Pump (Cole-Parmer, USA).

The process was carried out within 206 hours. The lactose concentration was monitored across time.

\section{RESULTS}

\section{Efficiency of the immobilization process}

Research on the amount of enzyme subjected to immobilization allowed obtaining a very high process efficiency (98.1-99.4\%). The commercial product (Sigma, G3665) diluted 20-fold was used, which corresponded to a protein concentration in the sample of $0.888 \pm 0.007$ $\mathrm{g} / \mathrm{L}$. A total of $10 \mathrm{~mL}$ of this solution was added to 20 mg of dry activated graphene. After the immobilization process, the enzyme surface concentration was in the range of $0.4115 \pm 0.0035 \mathrm{~g} / \mathrm{g}$ of carrier. Compared with results for other carriers ${ }^{14,15}$ the results in this study were quite satisfactory. 


\section{Activity of immobilized enzymes}

Enzyme activity was tested at $37^{\circ} \mathrm{C}$, which was the optimal temperature for this enzyme ${ }^{\mathbf{1 6}}$. The $\mathrm{pH}$ was adjusted to that of cow's milk (6.6) because the process of lactose hydrolysis very often pertains milk, among other substances, in order to obtain lactose-free products.

The immobilized enzyme activity was compared to the native enzyme activity. Fig. 6 presents data obtained for native enzymes in the range $0.15-0.94 \mathrm{~g} / \mathrm{L}$. The reaction was carried out at an initial lactose concentration equal to $1 \mathrm{~g} / \mathrm{L}$.

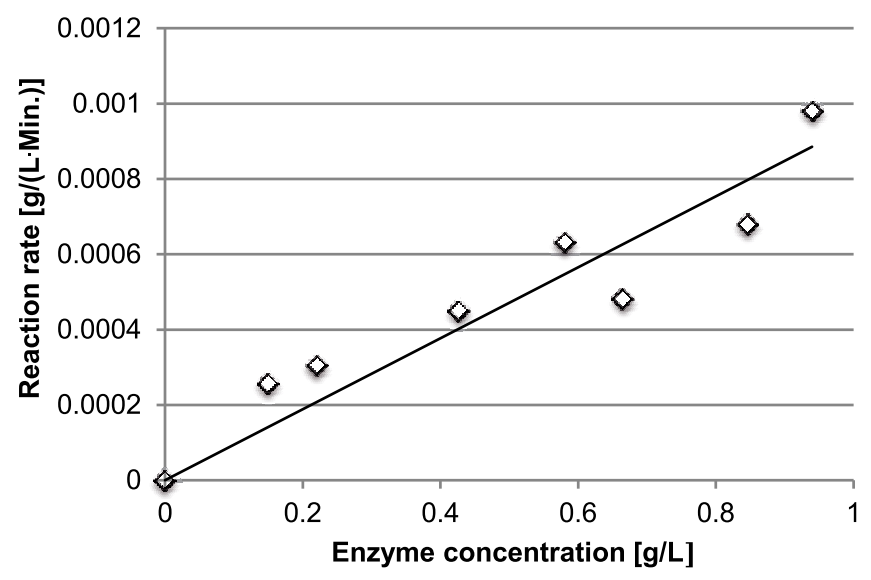

Figure 6. Rate of lactose hydrolysis with the native $\beta$-galactosidase (substrate concentration $1 \mathrm{~g} / \mathrm{L}, 37^{\circ} \mathrm{C}, \mathrm{pH}=6.6$ )

Under the same processing conditions (lactose concentration $1 \mathrm{~g} / \mathrm{L}, 37^{\circ} \mathrm{C}, \mathrm{pH}=6.6$ ), the average value (based on 6 independent reactions) of the initial reaction rate obtained with the immobilized enzyme was calculated to be $0.000483 \pm 0.000061 \mathrm{~g} /(\mathrm{L} \cdot \mathrm{Min}$.). The enzyme mass fed to the reaction in relation to the whole reaction volume was $0.883 \pm 0.007 \mathrm{~g} / \mathrm{L}$. This means that the enzymatic activity after immobilization was lower $(58 \%$ of the expected value). It was determined that under higher turbulence (220 RPM vs. 120 RPM), the reaction rate was the same; therefore, it could be assumed that in stirred tank reactor diffusive resistances do not significantly influence the processing rate. Thus the loss of enzyme activity was probably caused by immobilization procedure carried out for $3 \mathrm{~h}$ at $\mathrm{pH} 8.0,3^{\circ} \mathrm{C}$.

\section{Enzyme stability}

The enzyme in native form has relatively low stability. In Fig. 7, the average values from three different reactors are presented.

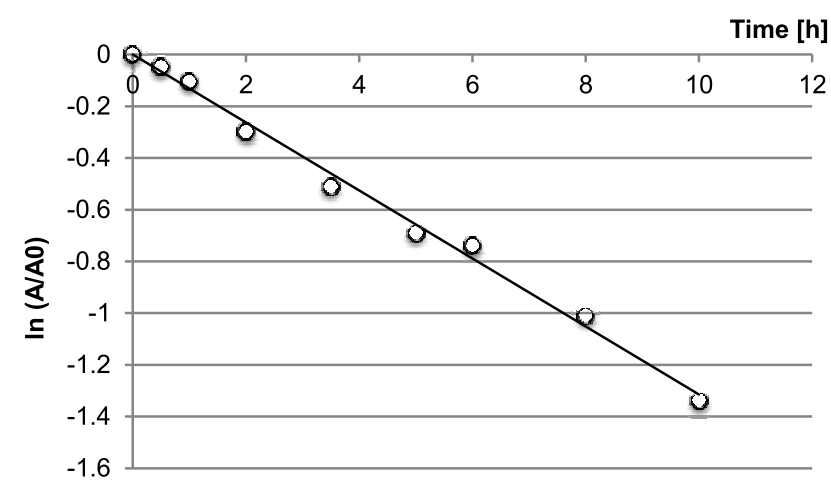

Figure 7. Stability of native $\beta$-galactosidase at $37^{\circ} \mathrm{C}, \mathrm{pH}=7.0$
Assuming that the inactivation process takes place according to first order kinetics, the inactivation constant was estimated using the value $0.13141 / \mathrm{h}$. The relative error for this value is $10.3 \%$. Using this value as a constant, the half-life was calculated as $5 \mathrm{~h}$. Based with these data, the stability of the immobilized enzymes was much higher. The activity of obtained preparations was monitored for 10 days. The average values obtained for three different preparations are presented in Fig. 8. The first-order inactivation constant with a relative error of $6.46 \%$ was estimated as $0.0042 \mathrm{1} / \mathrm{h}$. Thus, the half-life was calculated as $165 \mathrm{~h}$. This value indicates the high profitability of using the immobilized preparation.

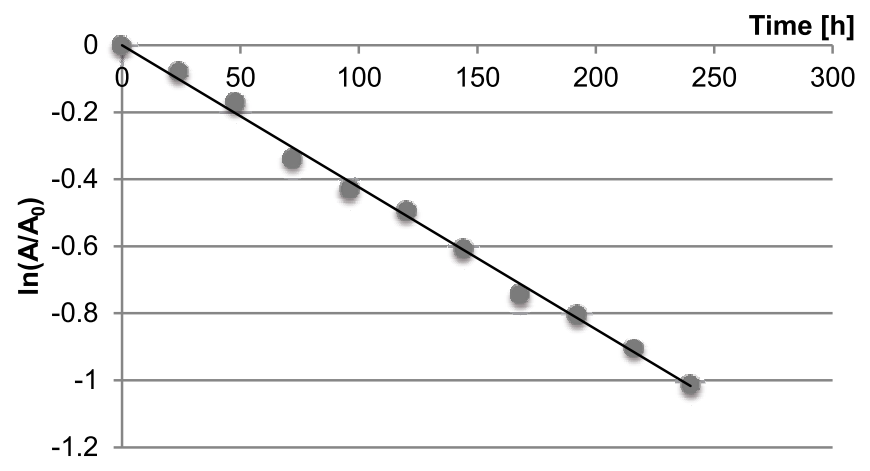

Figure 8. Stability of immobilized $\beta$-galactosidase at $37^{\circ} \mathrm{C}$, $\mathrm{pH}=7.0$

\section{Experiment of continuous processing}

High packing of the enzyme on the carrier, relatively high activity and, above all, very high activity in comparison to that of the stable native enzyme indicated high application potential of the obtained preparation. The greatest disadvantage is the difficulty with separation. Due to the size of the graphene flakes and their density, the standard process in a packed column ${ }^{17,18}$ is not a suitable solution. Additionally, the membrane process with recirculation of flakes (as it is the case of classical processes with biomass recirculation ${ }^{19,20}$ is not recommended due to the risk of mechanical destruction of the preparation. Therefore, a solution similar to the so-called submerged membrane ${ }^{\mathbf{2 1}}$ was proposed.

An appropriately selected mass of graphene flakes containing chemically bonded enzymes was suspended in dialysis membrane tubing (Spectrum ${ }^{\mathrm{TM}}$ Spectra/Por ${ }^{\mathrm{TM}}$ 3 RC, Fisher Scientific). The membrane cut off was set at $3.5 \mathrm{kDa}$, which allows free diffusion of lactose but restricts passage into the tube of proteins found in milk that could absorb on graphene.

It has been assumed that the milk is fed into the reactor after partial recovery of lactose (e.g., in the nanofiltration process ${ }^{22}$. The lactose concentration in the dosing stream is approximately 10 times lower than in raw milk, which means that it is equal to app. 4.65 $\mathrm{g} / \mathrm{L}$. The concentration of lactose in the stream leaving the reactor and inside the reactor was $1 \mathrm{~g} / \mathrm{L}$. At this substrate concentration, the reaction runs had a rate of $0.0005471 / \mathrm{min}$. This value was obtained by dividing the obtained reaction constant $(0.000483 \mathrm{~g} /(\mathrm{L} \cdot \mathrm{Min})$.$) by$ the enzyme concentration in test reactions $(0.883 \mathrm{~g} / \mathrm{L})$.

Therefore, when introducing $20 \mathrm{~g}$ of graphene flakes with $8.2 \mathrm{~g}$ of immobilized $\beta$-galactosidase into 1 litre of 
reaction volume, the residence time is estimated to be 14 hours. Because in the proposed process solution it is impossible to add a new enzyme portion during the processing run without enzyme inactivation, it was assumed that this time would be extended gradually. The obtained results are presented in Table 1 . The residence time was extended every 24 hours.

Table 1. The data obtained during continuous processing. Cow's milk diluted 10-times with $0.05 \mathrm{M}$ Tris- $\mathrm{HCl}$ buffer, $\mathrm{pH}$ 6.6, was dosed to the reactor with 20.17 $\mathrm{g}$ of graphene flakes with $8.27 \mathrm{~g}$ of $\beta$-galactosidase. The lactose concentration in the dosing stream was $4.652 \mathrm{~g} / \mathrm{L}$. The temperature was $37^{\circ} \mathrm{C}$

\begin{tabular}{|c|c|c|c|}
\hline Time [h] & $\begin{array}{l}\text { Residence } \\
\text { time [h] }\end{array}$ & $\begin{array}{c}\text { Lactose } \\
\text { concentration } \\
\text { in leaving } \\
\text { stream }[\mathrm{g} / \mathrm{L}]\end{array}$ & $\begin{array}{l}\text { Conversion degree } \\
\alpha=\left(C_{S, t} / C_{S, 0}\right) 100 \%\end{array}$ \\
\hline 0 & 14 & 0.997 & 78.57 \\
\hline 8 & 14 & 1.036 & 77.73 \\
\hline 24 & 16 & 0.988 & 78.76 \\
\hline 32 & 16 & 1.024 & 77.99 \\
\hline 48 & 17 & 1.066 & 77.08 \\
\hline 56 & 17 & 1.211 & 73.97 \\
\hline 72 & 19 & 0.980 & 78.93 \\
\hline 80 & 19 & 0.999 & 78.52 \\
\hline 96 & 21 & 0.995 & 78.61 \\
\hline 104 & 21 & 1.006 & 78.37 \\
\hline 120 & 24 & 1.028 & 77.90 \\
\hline 128 & 24 & 1.093 & 76.50 \\
\hline 144 & 26 & 0.997 & 78.57 \\
\hline 152 & 26 & 1.085 & 76.68 \\
\hline 168 & 28 & 1.214 & 73.90 \\
\hline 176 & 28 & 1.342 & 71.15 \\
\hline 192 & 31.5 & 0.925 & 80.11 \\
\hline 206 & 31.5 & 1.019 & 78.09 \\
\hline
\end{tabular}

During the first 152 hours, the system was stable, and the lactose concentration in the leaving stream was consistent with the assumed one. After this time, larger, but still acceptable, discrepancies in values were obtained. This level of accuracy means that the inactivation constant was well estimated, that the enzyme stability in milk was the same as in $0.5 \mathrm{M}$ Tris- $\mathrm{HCl}$ buffer, $\mathrm{pH}$ 6.6, and that the continuous processing was suitable. No diffusive resistances occurred if the graphene flakes were not directly mixed.

\section{CONCLUSION}

$\beta$-galactosidase was the first enzyme immobilized via divinylsulfone on graphene oxide flakes. The immobilization procedure, due to difficulties in separating the carrier, was quite arduous. However, the preparation produced very high stability compared to the stability of the native enzyme.

A processing solution for a continuous process was proposed. Placing the carrier with the catalyst in dialysis membrane tubing allowed avoidance of problems relating to the separation of the carrier and problems with resistance of flow through a compacted bed.

As shown by the results of the research, a membrane with a cut off of $3.5 \mathrm{kDa}$ allowed free diffusion of the substrate, and in the case of the lactose hydrolysis reaction, no diffusion resistance affected the speed of the process.
The developed immobilization method for graphene oxide flakes and the process solution for continuous processing can be applied to immobilization of any enzyme or biomolecule.

\section{ACKNOWLEDGEMENTS}

The project was partially carried out in the framework of the statutory activities of the Chemical Department of the Wrocław University of Technology No. 0401/0187/17 (studies related to $\alpha$-galactosidase immobilization and characterization), and partly in the framework of the NCN project No.2013/11/B/ST8/03672 (optimization of graphene oxide flakes separation and activation procedure).

\section{LITERATURE CITED}

1. Zhen, Z. \& Zhu H. (2017). Structure and Properties of Graphene, Academic Press.

2. Wang, Y., Li, Z., Wang, J., Li, J. \& Lin, Y. (2011). Graphene and graphene oxide: biofunctionalization and applications in biotechnology. Trends Biotechnol. 29(5), 205-212. DOI: 10.1016/j.tibtech.2011.01.008.

3. Talat, M. \& Srivastava, O.N. (2016). Deployment of New Carbon Nanostructure: Graphene for Drug Delivery and Biomedical Applications, Advances in Nanomaterials 383-395, DOI: 10.1007/978-81-322-2668-0_11

4. Lin, L.L., Chi, M.C., Lan, Y.J., Lin, M.G., Juang, T.Y. \& Wang, T.F. (2017). Facile immobilization of Bacillus licheniformis $\gamma$-glutamyltranspeptidase onto graphene oxide nanosheets and its application to the biocatalytic synthesis of $\gamma$-l-glutamyl peptides. Internat. J. Biol. Macromolec. 117, 1326-1333. DOI: 10.1016/j.ijbiomac.2017.11.153.

5. Zhang, Y., Zhang, J., Huang, X., Zhou, X., Wu, H. \& Guo, S. (2012). Assembly of Graphene Oxide-Enzyme Conjugates through Hydrophobic Interaction. Small 8(1), 154-159. DOI: 10.1002/smll.201101695.

6. Zhang, J., Zhang, F., Yang, H., Huang, X., Liu, H., Zhang, J. \& Guo, S. (2010). Graphene Oxide as a Matrix for Enzyme Immobilization. Langmuir 26(9), 6083-6085. DOI: 10.1021/la904014z.

7. Bolibok, P., Wisniewski, M., Roszek, K. \& Terzyk, A.P. (2017). Controlling enzymatic activity by immobilization on graphene oxide, Sci. Nat. 104: 36. DOI: 10.1007/s00114-0171459-3.

8. Kishore, D., Talat, M., Srivastava, O. \& Kayastha, A. (2012). Immobilization of $\beta$-Galactosidase onto Functionalized Graphene Nano-sheets Using Response Surface Methodology and Its Analytical Applications, Plos One 7(7):e40708. DOI: 10.1371/journal.pone.0040708.

9. Rodrigues, R.R., Berenguer-Murcia, A. \& FernandezLafuente, R. (2011). Coupling Chemical Modification and Immobilization to Improve the Catalytic Performance of Enzymes, Adv. Synth. Catal. 353(13), 2216-2238. DOI: 10.1002/ adsc. 201100163.

10. dos Santos, J.C.S., Rueda, N., Barbosa, O., FernandezSanchez, J.F., Medina-Castillo, A.L., Ramon-Marquez, T., Arias-Martos, M.C., Millan-Linares, M.C., Pedroche, J., del Mar Yust, M., Goncalves, L.R.B. \& Fernandez-Lafuente, R. (2015). Characterization of supports activated with divinyl sulfone as a tool to immobilize and stabilize enzymes via multipoint covalent attachment. Application to chymotrypsin. RSC Adv. 5, 20639-20649. DOI: 10.1039/C4RA16926C.

11. Zucca, P. \& Sanjust, E. (2014). Inorganic Materials as Supports for Covalent Enzyme Immobilization: Methods and Mechanisms. Molecules 19, 14139-14194. DOI: 10.3390/ molecules190914139. 
12. Trusek-Holownia, A. (2005). A catalytic membrane for hydrolysis reaction carried out in the two-liquid phase system - Membrane preparation and characterisation, mathematical model of the proces. J. Membr. Sci. 259(1-2), 74-84. DOI: 10.1016/j.memsci.2005.03.047

13. Miller, C.N. (1959). Use of dinitrosalicyle acid reagent for determination of reducing sugar. Anal. Chem. 81, 426-428.

14. Braga, A.R.C., Silva, M.F., Oliveira, J.V., Treichel, H. \& Kalil, S.J. (2014). A new approach to evaluate immobilization of $\beta$-galactosidase on Eupergit ${ }^{\circledR} \mathrm{C}$ : structural, kinetic, and thermal characterization. Quím. Nova 37, 5, 796-803. DOI: 10.5935/0100-4042.20140128.

16. Niu, D., Tian, X., Mchunu, N.P., Jia, Ch., Singh, S., Liu, X., Prior, B.A. \& Lu, F. (2017). Biochemical characterization of three Aspergillus niger $\beta$-galactosidases. Elect. J. Biotechnol. 27, 37-43. DOI: 10.1016/j.ejbt.2017.03.001.

17. Czyzewska, K. \& Trusek, A. (2018), Encapsulated catalase from Serratia genus for $\mathrm{H}_{2} \mathrm{O}_{2}$ decomposition in food applications. Pol. J. Chem. Technol. 20(4). DOI: 10.2478/pjct-2018-0052.

18. Fisher, J., Guidini, C.Z., Soares Santana, L.N., de Resende, M.M., Cardoso, W.L., Ribeiro, E.J. (2013). Optimization and modeling of lactose hydrolysis in a packed bed system using immobilized $\beta$-galactosidase from Aspergillus oryzae. J. Mol. Catal. B: Enzymatic 85-86, 178-186. DOI: 10.1016/j. molcatb.2012.09.008.

19. Barancewicz, M. \& Gryta, M. (2012). Ethanol production in a bioreactor with an integrated membrane distillation module. Pol. J. Chem. Technol. 66(2), 85-90. DOI: 10.2478/ s11696-011-0088-0.

20. Trusek-Holownia, A. (2008). Wastewater treatment in a microbial membrane bioreactor - a model of the proces. Desalination 221(1-3), 552-558. DOI: 10.1016/j.desal.2007.01.116 .

21. Chon, K., Lee, K., Kim, I.S. \& Jang, A. (2016). Performance assessment of a submerged membrane bioreactor using a novel microbial consortium. Bioresour.Technol. 210, 2-10. DOI: 10.1016/j.biortech.2016.01.013.

22. Atra, R., Vatai, G. \& Bekassy-Molnar, E. (2005). Investigation of ultra- and nanofiltration for utilization of whey protein and lactose. J. Foof Eng. 67 (3), 325-332. DOI: 10.1016/j. foodeng.2004.04.035. 